\title{
Assessment of Inaouene River Pollution for Potable Water Supply, Northern Morocco
}

\author{
Marouane Laaraj ${ }^{*}$, Lahcen Benaabidate ${ }^{1}$, Valérie Mesnage ${ }^{2}$ \\ 1 Laboratory of Functional Ecology and Environment Engineering, University of Sidi Mohammed Ben Abdellah, \\ FST Fes, Route d'Imouzzer P.O. Box: 2202, 30000 Morocco \\ 2 Laboratory of Continental and Coastal Morphodynamic (M2C), University of Rouen-Normandy. Place Emile \\ Blondel. 76281 - Mont-Saint-Aignan Cedex, France \\ * Corresponding author's e-mail: marouane.laaraj@usmba.ac.ma
}

\begin{abstract}
Under hydrological uncertainty and to secure the potable water supply for the Fez city with more than one million and a half inhabitants, the competent authority intends to bring water from the Idriss $1^{\text {st }}$ reservoir $30 \mathrm{~km}$ away, downstream the Inaouene watershed. The pollution risks as well as the contamination degree of surface water and sediments were assessed by monitoring the physicochemical characteristics of the water and sediment samples. The results revealed high values of chemical oxygen demand and chloride mainly linked to the uncontrolled liquid discharges. Calcium and magnesium showed also high concentrations that are due to the watershed geology, where carbonate rocks are dominant. The contents of some heavy metals remain relatively low and within the Moroccan standards. The metal contents in sediments show a low degree of the anthropogenic pollution. This led to conclude that the waters and sediments in the study area show relatively degraded quality and then could be used for water supply under continuous control.
\end{abstract}

Keywords: Idriss $1^{\text {st }}$ reservoir, Inaouene River, water, sediments, physicochemistry, contamination, Morocco.

\section{INTRODUCTION}

Water sources are increasingly exposed to contamination through the changes in the land use patterns, poor solid waste and stormwater management, inadequate wastewater treatment, aging infrastructure, as well as unbridled formal and informal urban expansion (World Bank 2017). Water resources such as lakes, reservoirs and rivers have an important role in ensuring the availability of water on Earth. They are the main source of water for the drinking, industrial and irrigation needs. Therefore, water scarcity is considered a limiting factor in the socio-economic development of a country (Bajraktari et al. 2019). However, the surface water pollution remains a major worldwide concern, caused by both natural processes and anthropogenic activities (Noori et al. 2010). They not only cause worsening of the water quality and its unsuitability for drinking, but also water eutrophication and extinction of some plant and animal species, leading to the destruction of ecosystems (Policht-Latawiec et al. 2017).

Pollutants are generally present in the water column and sediments in dissolved and / or particle-bound forms. Indeed, they can accumulate in the sedimentary areas and build up large stocks of pollutants in the Inaouene River, which is the main watercourse supplying the Idriss $1^{\text {st }}$ reservoir $\left(1186 \mathrm{Mm}^{3}\right)$, one of the largest dams in Morocco in terms of capacity and storage, from which the basin authority plan to reinforce the drinking water supply of the urban perimeter of the Fez city.

Despite the weakness of industrial activities in the Inaouene watershed upstream of the Idriss $1^{\text {st }}$ reservoir, this area recently recognized a significant population and agricultural development leading inevitably to the degradation of the surface water quality in the watershed. Indeed, this 
watershed receives all the raw domestic wastewater discharged by the city of Taza, Oued Amlil county and villages along its route. These liquid wastes have not undergone any prior treatment, due to the lack of a wastewater treatment plant. These liquid wastes end their course in the dam and then threaten the physicochemical quality of water and sediments in the watercourse and lately in the dam. Regarding this fact, the hydro-chemical monitoring remains useful and necessary to better localize the sources of pollution in the study area. Among the pollutants, the naturally accumulating heavy metals are the most concerned. These heavy metals may have a geological origin entering the river system by climatic erosion (Biney et al. 1991).

In natural aquatic ecosystems, heavy metals are found at low concentrations, typically nanograms or micrograms per liter (Zhang and Huang 1993). It is also important to examine their concentration in relation to other parameters that may affect dissolution, precipitation, accumulation and mobility (La Force et al. 1998).

Securing and sustaining the water resources for the expanding cities under increasing hydrological uncertainty and variability can be achieved through the mobilization of new water resources, improving the system efficiency and water conservation efforts.

\section{MATERIAL AND METHODS}

\section{Study area}

The Inaouene watershed is located in the Northern Morocco in the Eastern most part of the Sebou basin, between the parallels $(33.84 \mathrm{~N}$, $34.58 \mathrm{~N})$ and the meridians $(3.78 \mathrm{~W}, 4.91 \mathrm{~W})$. It covers an area of about $2720 \mathrm{~km}^{2}$ overlaying a part of the carbonate Middle Atlas and a part of the marly Pre-Rif domain (Fig.1). The watershed is characterized by a semi-arid climate (Naoura et al. 2012), cold in winter and hot in summer. It is subdivided between into three structural domains. To the North; the Prerif hills, the Middle Atlas Mountain and the Tazekka Paleozoic massif (Mesrar 2013) to the South. Thus, a variety of lithological outcrops with a well-developed vegetation cover in the South is more prevalent than in the North of the basin. These two factors influence the hydrographic network, which remains more important on the North than in the South.
(Naoura et al. 2012) highlighted that the Inaouene surface water presents a good quality upstream the city of Taza but after crossing the city the water becomes of poor quality due to the domestic wastewater discharge into the water body without any prior treatment.

\section{Water and sediment sampling and analysis}

The sampling technique is related to the purpose of the study. Indeed, targeted sampling was chosen, involving taking samples at the locations where contaminants are suspected or at the most sensitive points in the basin. The sampling was in July 2018 on 6 sites scattered on the watershed including the Idriss $1^{\text {st }}$ reservoir (Fig. 1).

The water samples from the effluent were taken as grab-samples using clean bottles quite far from the banks or edges as well as natural or artificial obstacles, outside the dead zones and avoiding the suspension of deposits. At the same sites, the sediment samples were taken from the first 10 centimeters. The conservation of water samples and sediments were made according to the general guide for the conservation and handling of samples according to ISO (1994). The water samples were treated with nitric acid, to preserve them for the determination of heavy metals (Kadriu et al. 2017)

The physicochemical parameters: temperature, $\mathrm{pH}$ and electrical conductivity were determined using a multi-parameter analyzer Type CONSORT - Model 835. BOD 5 was obtained by incubation of the volume of water chosen in a bottle sealed with Oxitop, in the dark and at $20^{\circ} \mathrm{C}$ for five days. This is performed by the respiratory method using a BOD-meter mark WTW, Model 1020T. The COD determined by potassium dichromate method at temperature of $148^{\circ} \mathrm{C}$ (Rodier et al. 2009). The nitrites were analyzed with the Zambelli reagent method. Nitrates were obtained with the molecular absorption spectrometry method.

The sulfates were determined with the nephelometric method. The determination of the total carbonates carried out by the determination of the alkalinity and more precisely of the TA and TAC titers. The chloride analysis was performed with the Mohr Method.

The suspended solids are determined by filtration of a volume of water on a $0.45 \mu \mathrm{m}$ filter. All these analyses were carried out according to the Rodier's protocol (2009). For the rest of the 


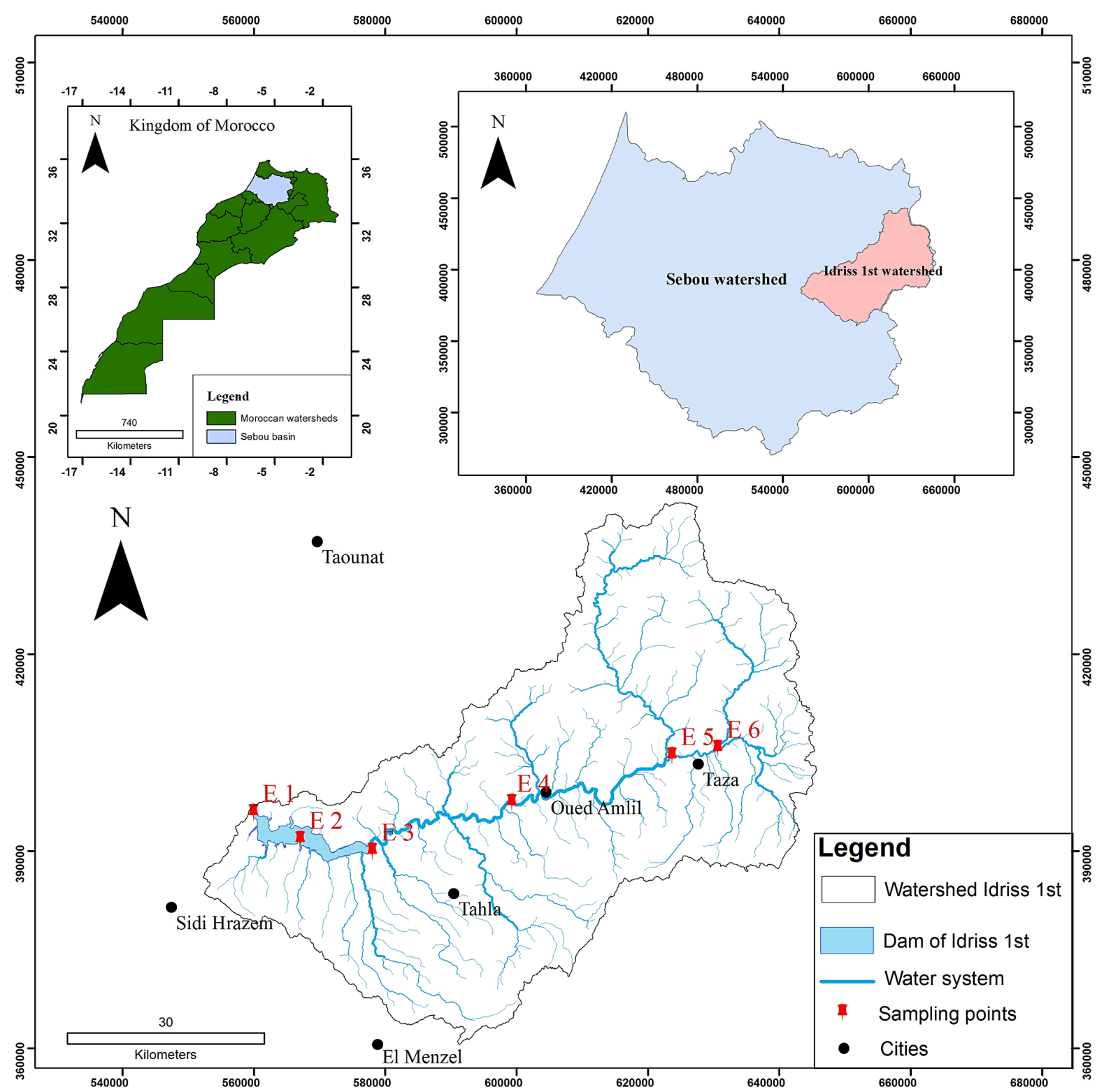

Figure 1. Situation of study area and sampling sites

elements, cations and major anions (magnesium, sodium, potassium, aluminum, manganese, iron, phosphate, etc.) were carried out using inductively coupled plasma atomic emission spectroscopy (ICP-AES) at the laboratory of the Innovation City of at the University of Sidi Mohamed Ben Abdellah of Fez, Morocco.

The determination of trace metal elements (TME) in sediments $(\mathrm{Ce}, \mathrm{Co}, \mathrm{Cu}, \mathrm{Li}, \mathrm{Ni}, \mathrm{Pb}, \mathrm{V}$, $\mathrm{Y}, \mathrm{Zr}, \mathrm{Nb}, \mathrm{Cr}, \mathrm{Sr}$ ) was carried out in the laboratory of the National Office of Hydrocarbons and Mines in Rabat, Morocco. The phosphorus analysis bound to calcium (P-Ca), iron (P-Fe), organic matter (P-OM) and soluble phosphorus was carried out at the M2C laboratory, University of Rouen-Normandy, France.

\section{RESULTS AND DISCUSSIONS}

\section{Water physicochemical characteristics}

The physicochemical indicators of the water quality are often subject to spatiotemporal variations induced by the anthropogenic activities that modify the characteristics of water and affect its quality (Karrouch and Chahlaoui 2009).

\section{$\mathrm{pH}$}

The $\mathrm{pH}$ is an important factor related to the natural conditions of the environment. This parameter informs about the aggressiveness of water regarding the various components (biotic and 
abiotic) of the receiving environment and conditions a large number of physicochemical equilibria. In the study area, the values of $\mathrm{pH}$ fluctuate between 8.2 and 8.8 (Fig. 2a) and reveal a slight increasing gradient from sites E1 to E4 and then decrease allowing to conclude that the $\mathrm{pH}$ is slightly neutral to moderately alkaline.

\section{Temperature}

The temperature of the water is strongly influenced by the environmental conditions related to the geographical location of the study area, the geology of the crossed lands, the hydrology of the ecosystem and especially the prevailing climate (Rodier et al. 1984). This is an essential parameter because it permits correcting the analysis parameters the values of which are related to the temperature such as conductivity and $\mathrm{pH}$. It catalyzes the chemical reactions in the water. For this investigation, the water temperature shows a slight variation. The minimum recorded at the site $\mathrm{E} 6$ is $21^{\circ} \mathrm{C}$ at sources coming from the karstic environments where temperatures are low. Then, the maximum is $28^{\circ} \mathrm{C}$ recorded at the site $\mathrm{E} 4$ and seems to be related to the sampling time which is the afternoon (Fig. 2b).

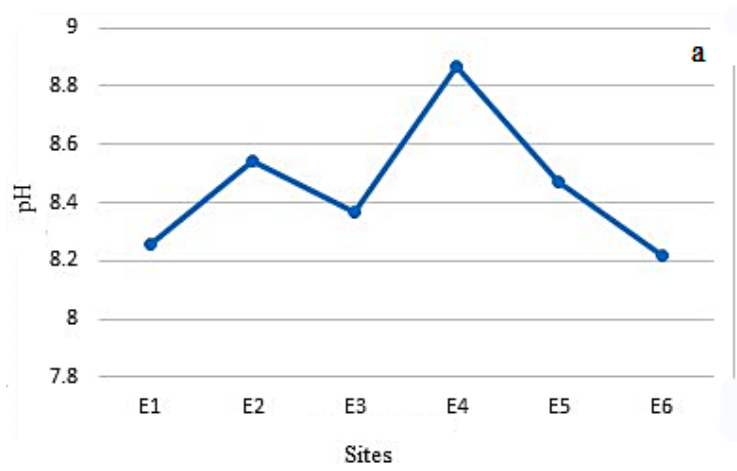

\section{Electrical conductivity}

The electrical conductivity (EC) is the capacity of water to conduct an electric current depending on its salinity that its self depends on the content of dissolved substances. It is also a function of the water temperature and, becomes more important when the temperature increases (Rejsek 2002). The electrical conductivity at the sites E1, E2, E3 corresponded to the samples taken at the dam as well as E6 which is near the sources, having low values with an average of $250 \mu \mathrm{S} \mathrm{cm}^{-1}$. However, the sites E5 and E4 show a relatively high EC of about $1052 \mu \mathrm{S} \mathrm{cm} \mathrm{cm}^{-1}$ (Fig. 3a). Indeed, these sites are considered highly mineralized according to the discharges loaded with high concentrations of polluting substances and secondarily to the soil leaching processes.

\section{Total suspended solids}

For the suspended solids (TSS), the site E5 displays the highest value of about $47.65 \mathrm{mg}^{-1}$ (Fig. 3b). This seems to be related to the liquid wastes issues from the urban zone of Taza city. Then, this value starts decreasing until $6.31{\mathrm{mg} 1^{-1}}^{-1}$ at the site E2 (Idriss $1^{\text {st }}$ reservoir

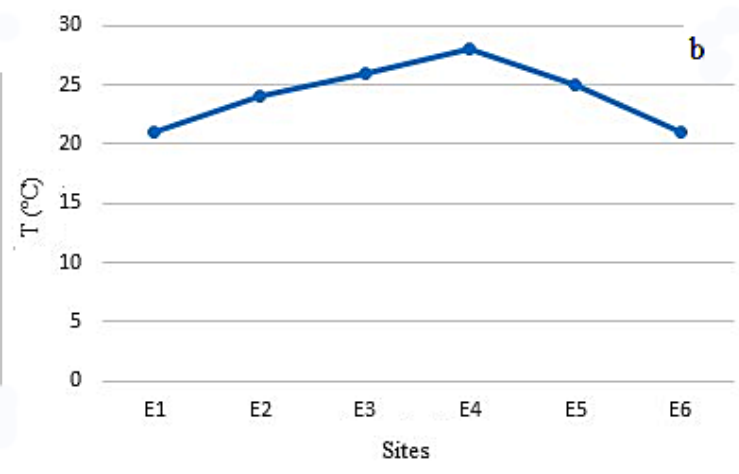

Figure 2. Spatial variation of $\mathrm{pH}(\mathrm{a})$, temperature (b)
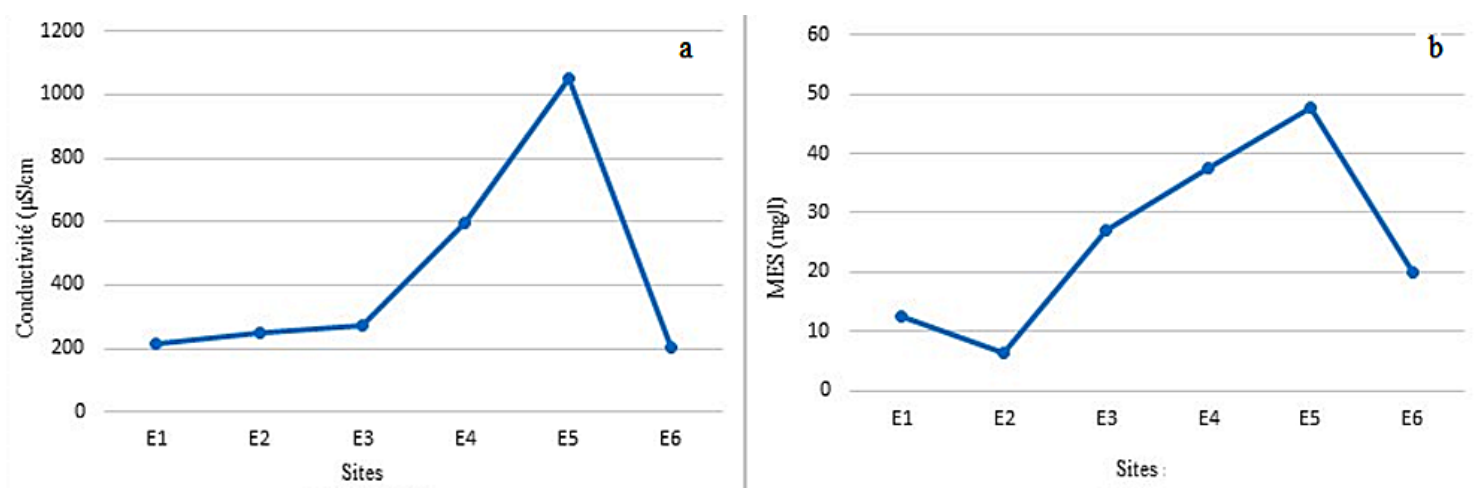

Figure 3. Spatial variation of conductivity (a) and Total suspended solids (b) 
center) corresponding to a calm environment conducive to decantation. Furthermore, at the site E1 located downstream of the dam, a slight increase of the suspended material is observed and could be induced by the evacuation of the dam water, which causes their disturbance.

\section{The chemical oxygen demand}

Chemical Oxygen Demand (COD) describes the need of oxygen to decompose organic matter chemically and results in reduced oxygen dissolved in the water (Rahim et al. 2019) for example, mineral salts and animal or plant organic compounds. This parameter allows appreciating the concentration of organic matter, mineral dissolved or suspended in water by the evaluation of the quantity of oxygen, in $\mathrm{mg}^{1^{-1}}$, necessary for the oxidation of these compounds. According to the obtained results (Fig. 4), the chemical oxygen demand evolves progressively from the site E3 to E5. This parameter has a maximum recorded value of $103 \mathrm{mg} \mathrm{l}^{-1}$, which reflects a contribution of the oxidizable materials by the domestic and industrial effluents from the urban area of Taza city, as well as oil mills waste concentrated in this area. At the E6 site, which is not exposed to any strong anthropogenic pollution, this parameter decreases significantly at the Idriss $1^{\text {st }}$ dam; the COD is relatively low evoking the effect of dilution that generates a low concentration of organic matter.

\section{The biological oxygen demand}

$\mathrm{BOD}_{5}$ is the molecular oxygen mass consumed by microorganisms for degrading the biodegradable organic matter in five days at $20^{\circ} \mathrm{C}$. This parameter is a perfect indicator of the amount of biodegradable organic matter in polluted natural water or wastewater. The results of $\mathrm{BOD}_{5}$ evolve in a different way than that of COD (Fig. 5). From sites E6 to E3, the values of $\mathrm{BOD}_{5}$ show the highest values with a slight decrease at E5 site due to the enrichment in organic matter by the effluents of Taza city and Oued Amlil urban areas, subsequently, the values begin decreasing until approaching $0 \mathrm{mg} \mathrm{l}^{-1}$ at the exit of the reservoir which proves that it is about the unpolluted water.

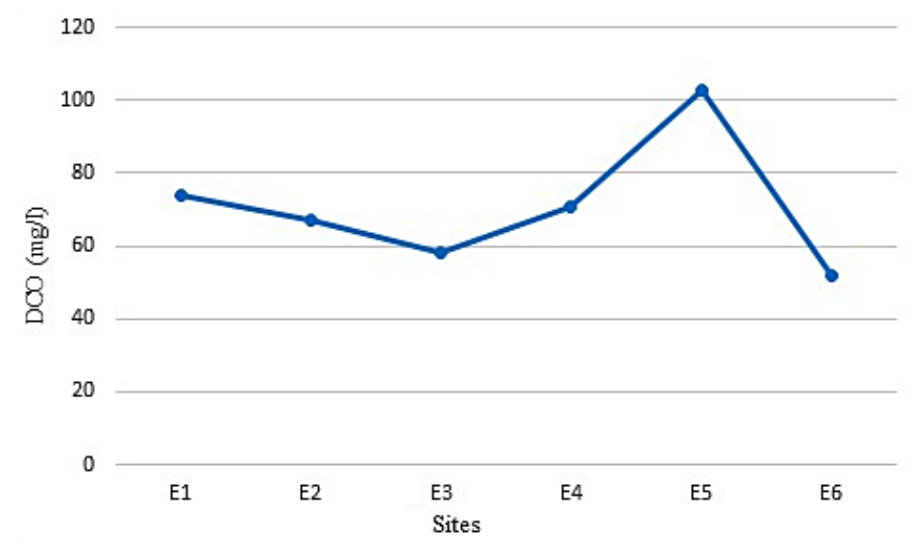

Figure 4. Spatial variation of COD

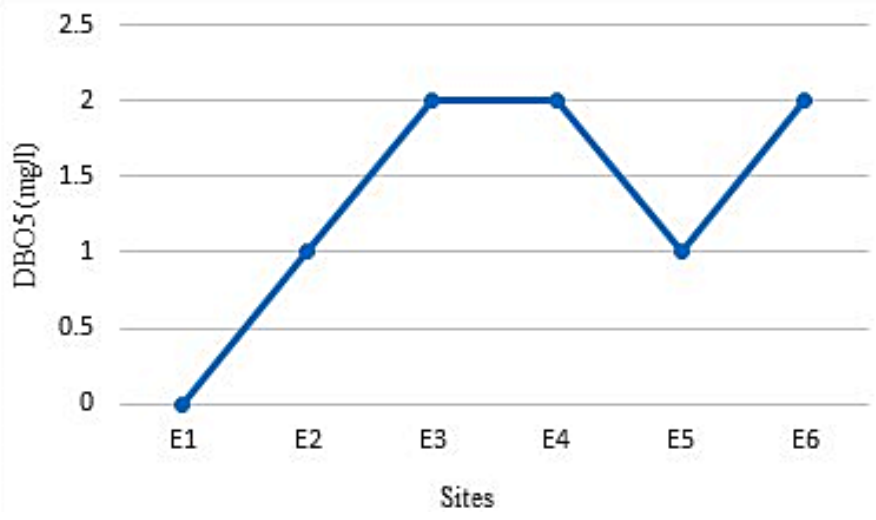

Figure 5. Spatial variation of $\mathrm{DBO}_{5}$ 


\section{Chloride}

The chloride concentration is very important almost on all the sampling sites (Fig.6A), except the lands E6 site which marks the lowest content in $\mathrm{Cl}^{-}\left(51.7 \mathrm{mg} \mathrm{1}^{-1}\right)$ and conversely, the site E5 reaches the maximum value induced by River water crossing Taza city and Oued Amlil county and receiving all their liquid wastes. This value begins decreasing progressively until the River arrival at the dam (E1) which highlights a dilution process during its course. The sulfate values vary in the same way as chloride. The high $\mathrm{SO}_{4}{ }^{2-}$ concentration amounts to $217 \mathrm{mg} \mathrm{l}^{-1}$ (Fig. 6A) at the site E5 and this could be explained by leaching the evaporites rocks widespread in this region, and to sulfates issued from fertilizers used in agriculture.

\section{Nitrogen}

The nitrogen pollution can be estimated by the determination of the nitrate and ammonium ion contents. The nitrate ions $\left(\mathrm{NO}_{3}^{-}\right)$represent the most soluble form of nitrogen. Its presence in the surface water is linked to the intensive use of fertilizer products. In the study area, nitrates and nitrites in water are in low concentrations not exceeding $3 \mathrm{mg} \mathrm{l}^{-1}$ (Fig.6a). This is the result of water uncontaminated by nitrogen.

\section{Calcium and magnesium}

Calcium $\left(\mathrm{Ca}^{2+}\right)$ and magnesium $\left(\mathrm{Mg}^{2+}\right)$ are present in crystalline and sedimentary rocks. They are very soluble and are therefore widely represented in most waters. In the study area, these two elements have high concentrations in water, especially upstream the dam and they decrease slightly downstream. This is the result of water hardness in the Inaouene watershed. Indeed, this
River drains on calcareous and dolomitic outcrops of the Northern Middle Atlas as well as the deposits rich in the sulfates of magnesium and calcium of the Prerif zone (Naoura 2012). They threaten the water quality by provoking the anaerobic phenomena during their transformation into sulfate by consuming the water oxygen (Bajraktari et al. 2019). Besides, sodium is present with significant values at the sites E5, E4 which reaches $36.6 \mathrm{mg} \mathrm{1}^{-1}$ (Fig. 6b). This increase is related to the domestic and industrial discharges. Then, a decrease in $\mathrm{Na}^{+}$values is noted according to the dilution process during its flow towards the dam.

\section{Trace elements}

Regarding heavy metals, seven elements $\mathrm{Cd}$, $\mathrm{Al}, \mathrm{Cr}, \mathrm{Pb}, \mathrm{Cu}, \mathrm{Fe}$ and $\mathrm{Zn}$ were investigated in this study (Fig. 6B) and constitute the most studied elements in Moroccan surface waters. Certainly, even at low concentrations, the ecological and health impacts of these metals may be important. These trace elements have the contents that vary between $0.04 \mathrm{mg} \mathrm{l}^{-1}$ and $1 \mathrm{mg}^{1^{-1}}$. These low values allowed to state that these elements right now do not harm the surface water in the Inaouene watershed and its dam. Indeed, the concentrations of these trace elements remain lower compared to the Moroccan standards.

According to the decree of the ME-MPUPHE (2002), defining the surface water quality grid that allow classifying the Inaouene watershed surface water according to their quality in chemical elements, using the conventional colors created in Article 8 of this decree (Fig. 7).

The physicochemical quality of water, especially at the site E5, is more or less poor regarding the high concentrations of chemical elements under the anthropogenic impact. Meanwhile, the Inaouene River flows in the vicinity the Taza city and Oued Amlil County and constitutes then the
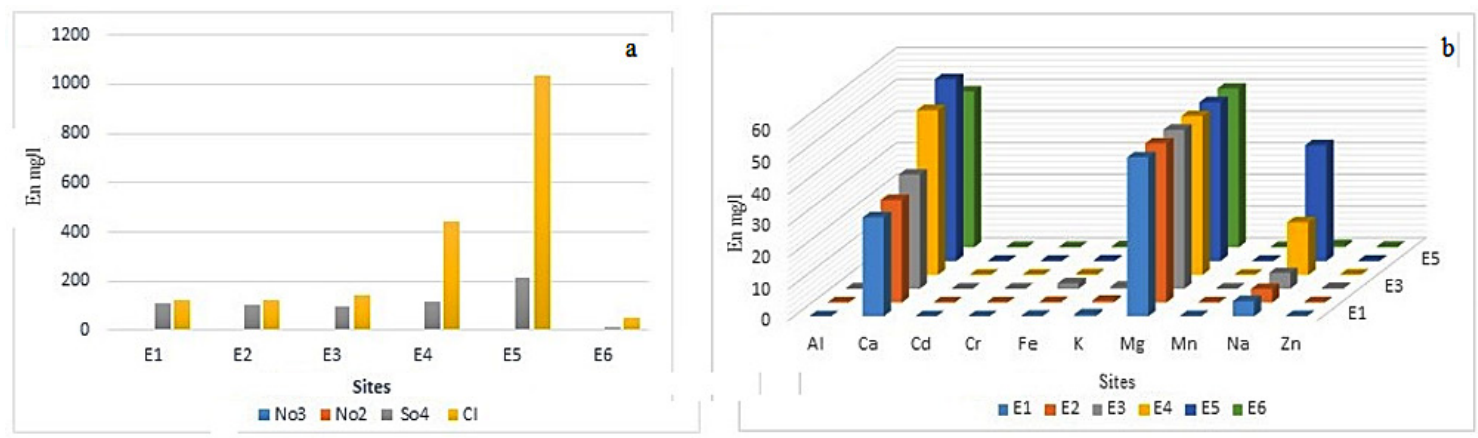

Figure 6. Spatial variation of chemical elements 


\begin{tabular}{|c|c|c|c|c|c|c|c|c|c|c|c|c|c|}
\hline Sites & $\mathrm{T}^{\circ} \mathrm{c}$ & $\mathrm{pH}$ & $\mathrm{CE}$ & $\mathrm{DBO} 5$ & $\mathrm{DCO}$ & $\mathrm{NO} 3$ & $\mathrm{SO} 4$ & $\mathrm{Cl}$ & $\mathrm{Cd}$ & $\mathrm{Cr}$ & $\mathrm{Fe}$ & $\mathrm{Mn}$ & $\mathrm{Zn}$ \\
\hline E1 & & & & & & & & & & & & & \\
\hline E2 & & & & & & & & & & & & & \\
\hline E3 & & & & & & & & & & & & & \\
\hline E4 & & & & & & & & & & & & & \\
\hline E5 & & & & & & & & & & & & & Excellant quality \\
\hline E6 & & & & & & & & & & & & & Good quality \\
\hline
\end{tabular}

Figure 7. Physicochemical quality in the study area

main receptor of their row liquid. This quality improves progressively according to the dilution process and then the water becomes medium and lately seems to be recovered at the dam.

\section{Physicochemical characteristics of sediments}

Sediment is a material derived from erosion, transported and deposited by the watercourse. It acts as a reservoir of metal elements that can be transferred partly to water. Metals in general and heavy metals in particular play a crucial role in the pollution of rivers. Therefore, the concentration of some metals is beneficial, whereas others are harmful and toxic (Ejupi et al. 2018). Besides, the metals are not fixed permanently and can then be released to the water column during a change in the environmental conditions, such as the potential Hydrogen $(\mathrm{PH})$, redox potential $(\mathrm{PE})$, the presence of organic chelators and hydrodynamics (Forstner 1987). Hence, the importance of investigating the content of traces elements in the River media in order to highlight the River pollution, of a natural origin or regarding an anthropogenic activity.

\section{Major elements}

According to the Inaouene Watershed geology characterized by calcareous and dolomitic outcrops of the Northern Middle Atlas, as well as the carbonate terrains of the Pre-rifan zone, the agents of erosion (wind, rain, frost) tear off fine particles or whole fragments of carbonated rocks. Then, these elements are moved to the lowest point corresponding to Inaouene River, so that the analysis of results (Fig. 8) showed that the sediments in the study area are very rich in calcium carbonate reaching $51 \%$ on the E5 site except for E2 site (Middle of the dam) shows that the $\mathrm{CaCo}_{3}$ values are low with $14.2 \%$, consequence of the solubility of carbonate in water.

\section{Loss of ignition}

The loss on ignition makes it possible to identify the total organic matter content in sediments. It is among the main pollutants of the aquatic environments. The obtained results show that the loss on ignition varies between a maximum recorded at E2 site (1.8\%) and a minimum of $0.8 \%$ on E4 site (Fig.9). The concentrations remain relatively low but they present a harm that threatens the quality of waters and sediments. The source of this pollutant is essentially related to domestic, industrial (oil mill) and agricultural discharges.

\section{Sediment granulometry}

The grain size allows determining the distribution of sediment particles along the Inaouene River and the Idriss $1^{\text {st }}$ dam in the classified categories according to their sizes and also providing the relative proportions of these categories, as a

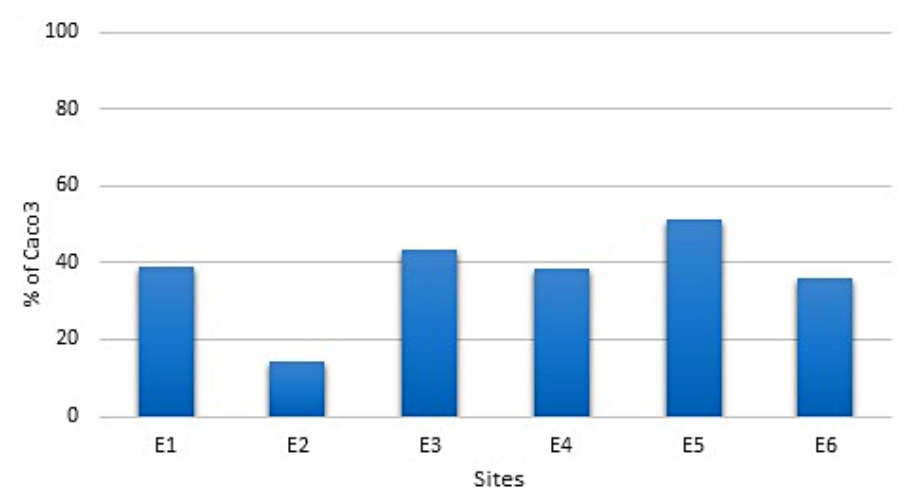

Figure 8. Spatial variation of $\mathrm{CaCO}_{3}$ in sediments 


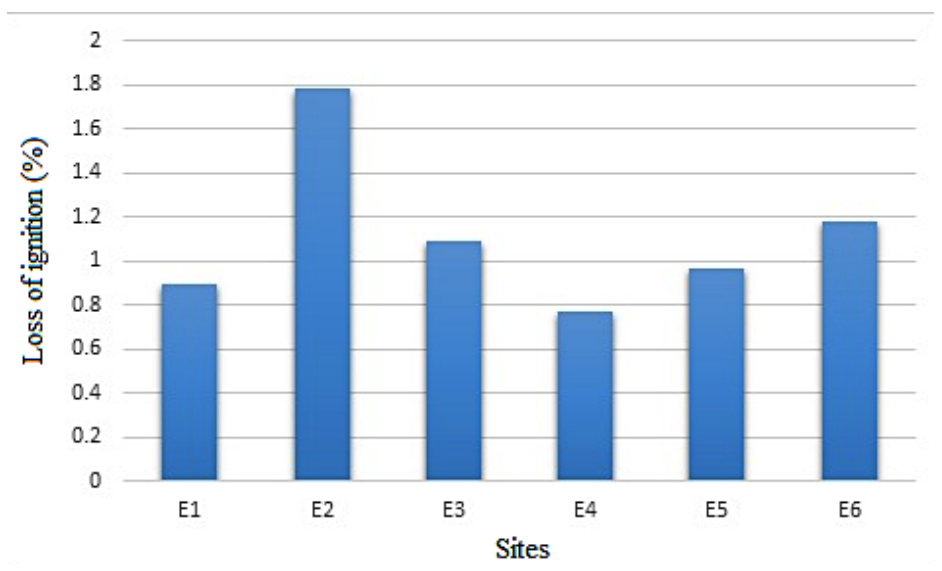

Figure 9. Spatial variation of loss on ignition in sediments

percentage of the mass of total sediment and subsequently deducing the texture of the studied soil. The result analysis (Fig.10) shows a variation in the proportions of the various size classes. The coarse deposits are the most dominant at the Inaouene River (sites E4, E5, E6). Closer to the dam (sites E2, E3), the fine elements appear then they dominate with proportion up to $83.4 \%$. Conversely, at the E1 site that is located just downstream the dam, the gravels have the highest percentage of $65.2 \%$, reflecting a similar character of the Inaouene River.

\section{Trace elements in sediments}

\section{Strontium}

Strontium is mainly abundant in evaporitic rocks. All waters leaching these formations show a close relationship between the strontium and calcium or sulfate levels (Meybeck 1986).

The strontium analysis result shows a high rate in all sites except E2. This high rate (579 ppm) (Fig. 11) should be related to the impact of pollution of effluents issued from the urban zones of Taza and Oued Amlil and the public landfills loaded with strontium.

\section{Lead}

The lead contents in sediments are characterized by the highest levels in all sites. The peak concentrations are recorded in the E5 site (70 ppm) that is exposed to pollution by urban effluents. It should be noted that these levels largely exceed those described for the unpolluted sediments, i.e. 19 ppm (Forstner and Salomons 1980), also the normal composition of the continental crust which is between 12.5 and 20 ppm (Taylor 1964). Lead solubility is low in waters so that its level in water is relatively low. Both the content and toxicity of lead are influenced by hardness, $\mathrm{pH}$, alkalinity, and oxygen concentration (Tjahjono et al. 2017).

\section{Zinc}

The analysis of the zinc results show that concentrations vary between $72 \mathrm{ppm}$ on E2 site and 120 ppm on E6 site, knowing that the natural

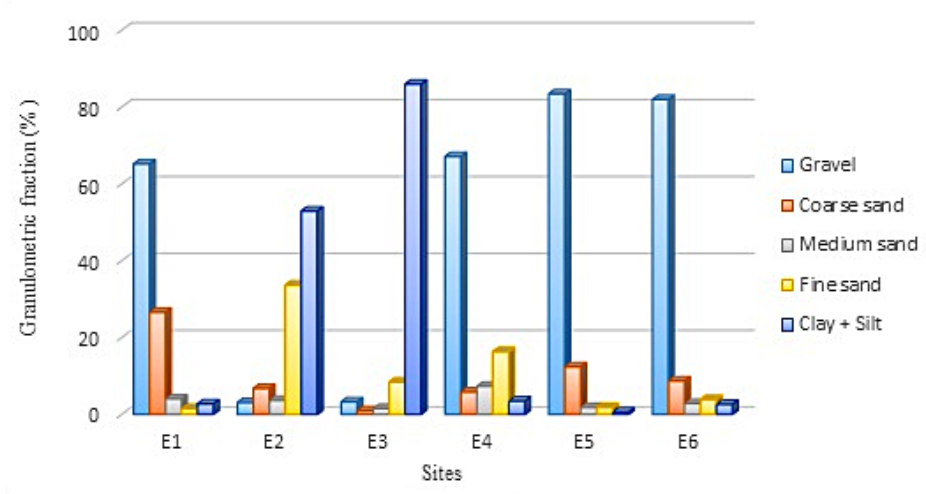

Figure 10. Spatial variation of particle size in sediments 
concentration of zinc in the Earth's crust varies between 10 and 300 ppm (Malle 1992), which allowed us to say that this element presents no harm in the Inaouene watershed.

\section{Copper}

The obtained results reflect the maximum concentration at the E6 site of about $46 \mathrm{ppm}$ and then this concentration decreases progressively towards downstream. However, at E3 site, a small rise in concentration is recorded and seems to be due to the Oued Amlil county waste discharge, but these concentrations remain low regarding the Moroccan standards.

\section{Barium}

The barium results show the highest concentrations in the sediments among all the other studied elements. Like strontium, the barium is associated with carbonated and sulfated ions. It is thus in the form of barite $\left(\mathrm{BaSO}_{4}\right)$ and whitherite $\left(\mathrm{BaCO}_{3}\right)$ and is poorly soluble when it is in the form of sulfate (El Bouch 1996).

The highest concentration upstream the E6 site reaching $750 \mathrm{ppm}$ seems to be of natural origin. Indeed, a mining activity of barium is located in the area. This concentration decreases to 179 ppm in the Idriss $1^{\text {st }}$ reservoir. Conversely, at the exit of the dam where the quantity of water is low, the concentration in barium increases again and reaches $1081 \mathrm{ppm}$. This could be related to the lack of dilution process. For the rest of trace elements $(\mathrm{Co}, \mathrm{Li}, \mathrm{Ni}, \mathrm{Ni}, \mathrm{Y}, \mathrm{Nb})$, they are present with low concentrations and seem to have no negative effect on the sediment quality. Furthermore, the hazardous heavy metals analyzed were below the limit of detection.

\section{Phosphorus}

Phosphorus in sediments is mainly due to the flow of particulate organic matter in the form of detritus (Alzieu 1999). Indeed, phosphorus is considered as the factor generating the eutrophication phenomenon. The quantity of phosphorus in the studied samples is high, with a maximum of 750 ppm on E5 site (Fig.11). Furthermore, the concentration of phosphorus remains high mainly between the urban zones of Taza and Oued Amlil according to their discharges. Then, the contents begin to decrease towards the dam. These results confirm the high rate of organic matter in the sediments of the Inaouene watershed.

The phosphorous-iron fraction represents a small portion (Fig. 12) on average 6\%. Spatial evolution of this fraction shows that the highest levels are recorded at station E6 and they decrease significantly between E5 and E3 and rise very slightly at $\mathrm{E} 5$. The presence of oxic layers on sediment surface favors the adsorption of phosphorus by iron (Jensen et al. 1992).

The phosphorous-organic matter fraction represents such a high concentration (on average $15 \%$ ). A maximum on E6 and as the P-OM values decrease regularly between E5 and E3 (Fig.12) and there appears to be a slight increase due to domestic discharges from habitats near the dam.... Phosphates can form complexes with organic matter and then a complex with iron (Taoufik et al. 2002),

The soluble fraction is close to zero (Fig. 12), while the P-Ca fraction represents the largest fraction of PT in sediments (on average $63 \%$ of PT). The concentrations distribution of this fraction is much more variable, with sediments ranging from $153 \mu \mathrm{g} \mathrm{g}^{-1}$ dry sediment at E6 to $485 \mu \mathrm{g}$

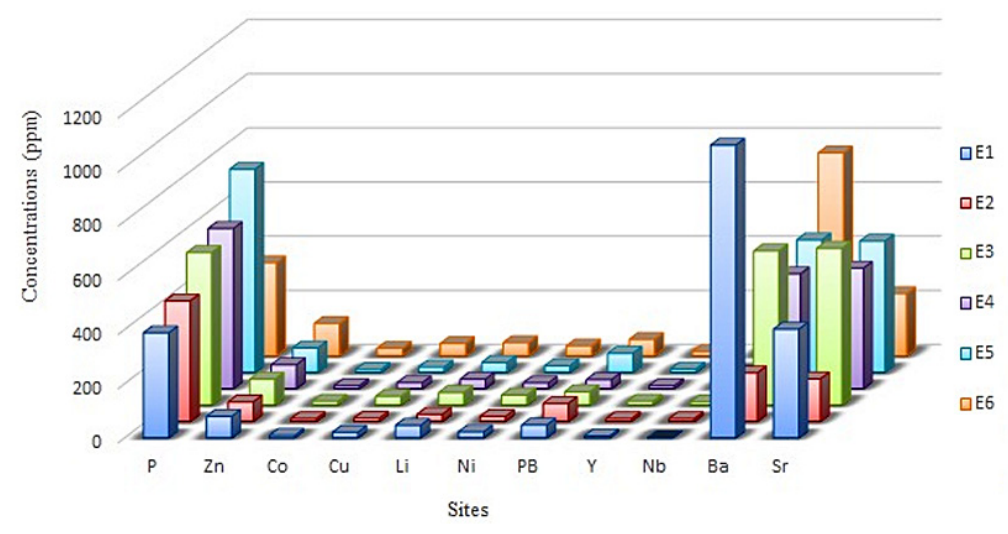

Figure 11. Spatial variation of chemical elements in sediments 


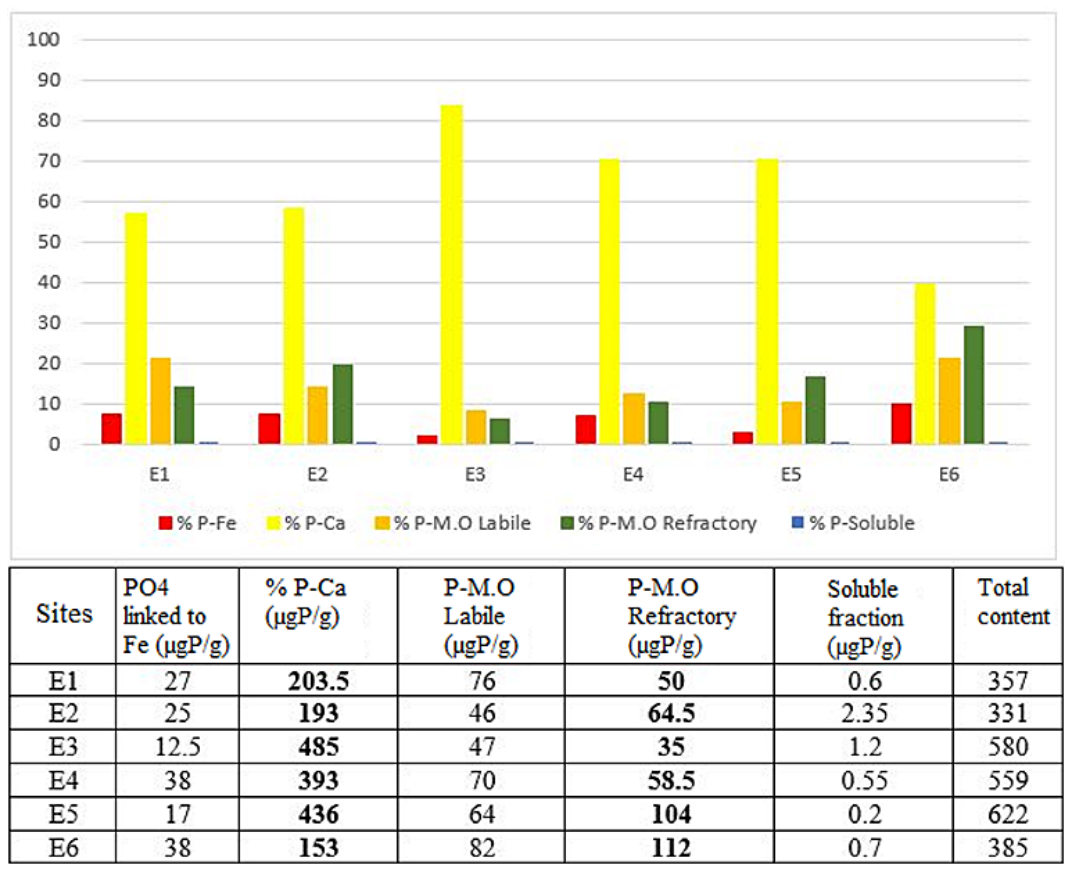

Figure 12. Spatial variations of the different P-fractions.

$\mathrm{P} \mathrm{g}^{-1}$ dry sediment at E3. This variation is mainly due to the accumulation of phosphorus at the reservoir entrance, where it collects all the water in the basin under the effect of runoff. In the sediments, calcium carbonate adsorbs the excess that cannot be bound to iron, although precipitation of calcium-bound phosphorus appears to be the main storage route in the sediments (Golterman 1988). This P-Ca fraction has long been considered to be poorly mobilizable, but it can lead to a phosphate release following a decrease in $\mathrm{pH}$ (Taoufik et al. 2002).

\section{Principal component analysis (PCA)}

\section{Relationships between anions and physical parameters}

The matrix and the correlation circle below, obtained by the XLSTAT software, between anions and analyzed physical parameters allow revealing the correlations between these variables:

The projection of variables on the factorial plane F1-F2 (Fig. 13a) highlights that the axis $\mathrm{F} 1$ expresses $46.2 \%$ of the variance and it is determined by $\mathrm{NO}_{2}^{-}, \mathrm{pH}, \mathrm{T}, \mathrm{Cl}, \mathrm{EC}, \mathrm{COD}, \mathrm{SO}_{4}^{2-}$.
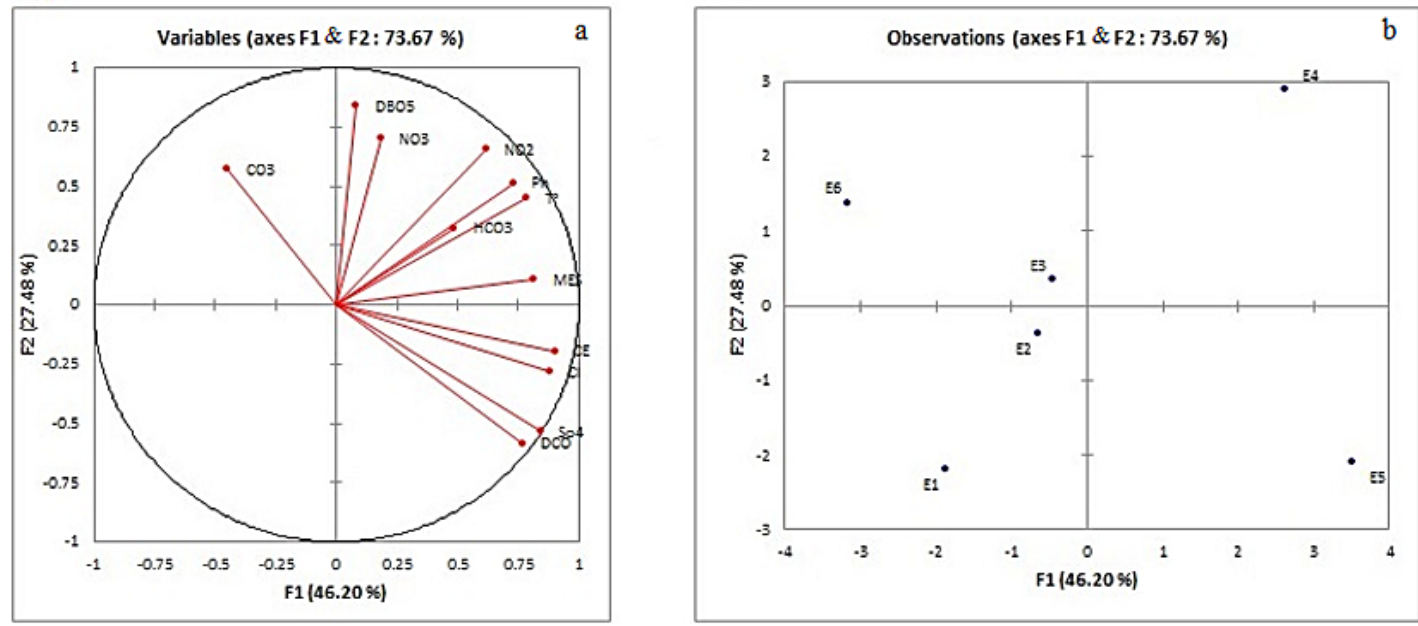

Figure 13. Anion correlation circle and physical parameters analyzed in waters (a) and representation map of sampled sites (b) 
The $\mathrm{F} 2$ axis expressing $27.5 \%$ of the variance is determined by $\mathrm{BOD}_{5}$ and $\mathrm{NO}_{3}^{-}$. Strong and positive correlations between anions $\left(\mathrm{SO}_{4}^{2-}, \mathrm{Cl}^{-}\right)$and between physical parameters $(\mathrm{T}, \mathrm{pH})$ are noted. Similar correlations are observed between anions and physical parameters $\left(\mathrm{T}, \mathrm{NO}_{2}^{-}\right) ;\left(\mathrm{pH}, \mathrm{NO}_{2}^{-}\right)$; $\left(\mathrm{EC}, \mathrm{Cl}^{-}\right)$. It should be noted that the presence of chlorides with high concentrations favors the increase of the electrical conductivity and, when the $\mathrm{pH}$ and the temperature reaches certain thresholds favor the increase of the nitrite concentrate ions in water.

The analysis of sites representation map (Fig.13b) reveals that the E4 and E5 sites have the highest concentrations of anions, with the highest percentages in terms of physical parameters, whereas the E6 site remains characterized by the presence of $\mathrm{CO}_{3}{ }^{2-}$.

\section{Relationships between major cations and metallic elements}

The six samples taken from the Inaouene River and the Idriss $1^{\text {st }}$ dam highlight several axes. The first two axes express the maximum of the variance $(65.4 \%)$. The information given by the axis 1 corresponds to $36.6 \%$ of the variance and the axis 2 represents $28.7 \%$. The distribution of the physicochemical variables according to the F1-F2 plane (Fig.14a) shows globally, weak positive and negative correlations. The only strong positive correlations are observed between the following pairs: $\left(\mathrm{Na}^{+}, \mathrm{Ca}^{2+}\right) ;\left(\mathrm{Na}^{+}, \mathrm{k}^{+}\right) ;\left(\mathrm{Al}^{3+}\right.$, $\left.\mathrm{Cd}^{2+}\right) ;\left(\mathrm{Fe}^{2+}, \mathrm{Zn}^{2+}\right)$. This allowed understanding the behavior of major cations and their affinities to other trace metal elements.
The superposition of the sites distribution map (Fig.14b) with the correlation circle provides an idea of the characteristics of the different sites (E1, E2, E3, E4, E5) regarding their trace elements and cations contents. The E4 and E5 sites are characterized by a high content of cations, while the E3 site is characterized by the presence of trace metal elements i.e. $\mathrm{Zn}^{2+}, \mathrm{Fe}^{2+}$. The $\mathrm{E} 6$ site highlights the presence of only one trace element; $\mathrm{Cd}^{2+}$. However, the other sites have moderate values for trace elements.

\section{Relation between the contents of metallic elements}

Correlations and positive trends suggest a partly common origin and/or chemical similarities (Knudsen et al. 1977). This common origin may be natural and/or related to the anthropogenic activity. Negative trends may be the consequence of different chemical behaviors between metals.

The projection of variables and individuals was performed on two axes, which represent $67.1 \%$ of the total variance. Axis 1 combines $47 \%$ of the total variance, and the second axis $20 \%$ (Fig.15a).

The results of the PCA show a strong positive correlation between the following elements: $\mathrm{Ni}$ $\mathrm{Zn}, \mathrm{Zn}-\mathrm{Co}, \mathrm{Cu}-\mathrm{Zn}, \mathrm{Cu}-\mathrm{Ni}, \mathrm{Ni}-\mathrm{Y}$ and are related to the $\mathrm{F} 1$ axis, whereas $\mathrm{Sr}$ and $\mathrm{Pb}$ are related to the F2 axis. From the correlation circle, the phosphorus is negatively correlated with the F1 axis. The high coefficient of correlation between the different metals means that they originate from the same source.
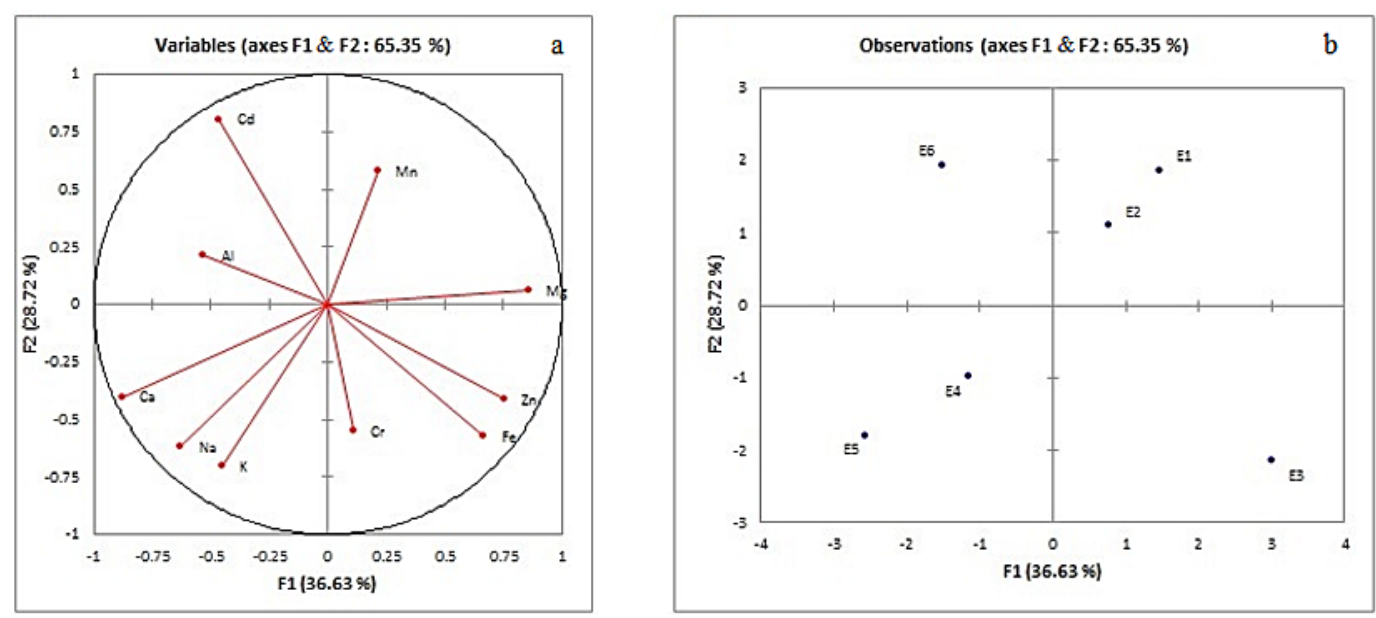

Figure 14. Correlation circle of major cations and metallic elements analyzed in waters (a) and representation map of the sampled sites (b) 

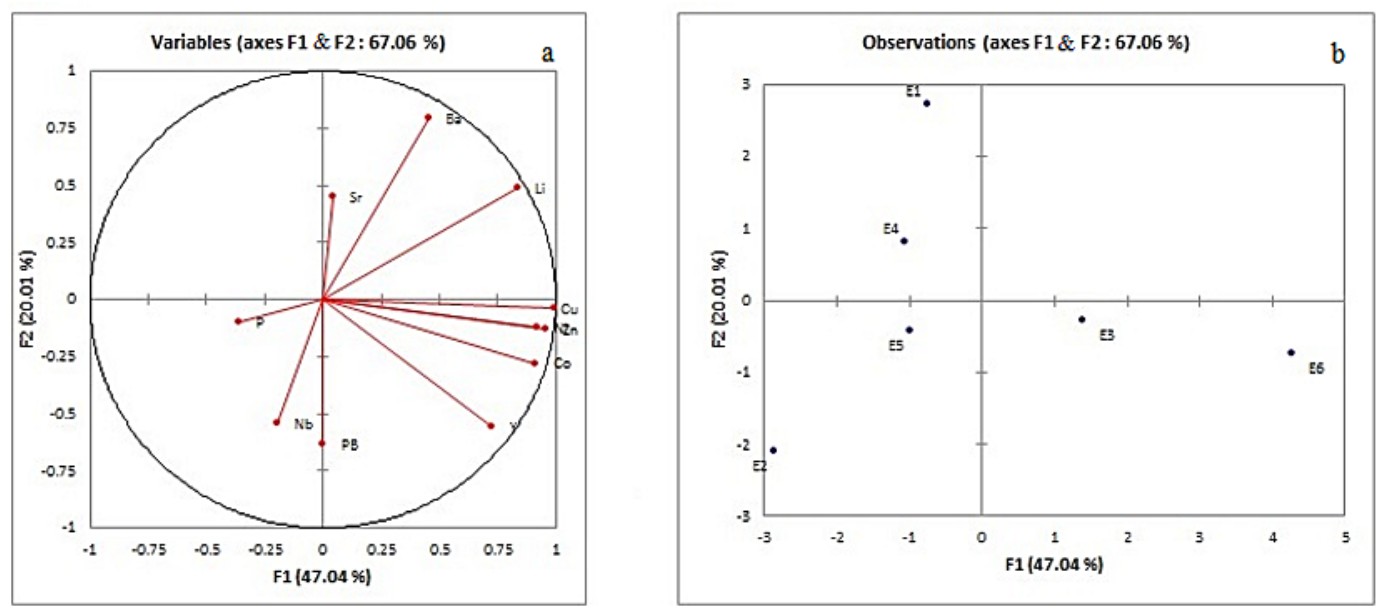

Figure 15. The correlation circle of trace elements in sediments (a) and the representation map of sampled sites (b)

According to the representation map of the sampled sites (Fig.15b), the factorial axis F1 reflects the sites (E5, E3, E6) characterized by high levels of metallic trace elements consisting on the following group ( $\mathrm{Li}, \mathrm{Cu}, \mathrm{Zn}, \mathrm{Ni}, \mathrm{Co}, \mathrm{Y}$ ) and P. Furthermore, the F2 axis on which is the E1 site is characterized by the presence of strontium contents.

\section{CONCLUSION}

The water of the Inaouene River and Idriss $1^{\text {st }}$ dam devoted to irrigation and supplying some cities and counties with drinking water were investigated. The obtained results highlight that these waters have the concentrations of pollutants that sometimes exceed the standards, especially downstream of urban zones of Taza city and Oued Amlil County which generate significant amounts of wastewater that is discharged directly into watercourses without any prior treatment and also solid waste. As a result, the preservation of water resources becomes imperative in the face of the degradation of these aquatic ecosystems and requires the establishment of treatment plants and landfills for these two main urban zones in the watershed. Globally, the surface water of the Idriss $1^{\text {st }}$ reservoir remains of good quality for reinforcing the drinking water supply of the urban area of the Fez city.

\section{Acknowledgements}

We would like to express our special thanks and gratitude to the France - Maghreb (Algeria,
Morocco and Tunisia) collaboration that gave us the excellent opportunity to do the wonderful project PHC - Maghreb 17MAG04 on the topic: Quality of dam lakes in the Maghreb, siltation and eutrophication, for an integrated management of drinking water resources.

\section{REFERENCES}

1. Alzieu C. 1999. Dragages et environnement marin: état des connaissances $=$ Dredging and marine environment: state of the art. Ifremer, Nantes.

2. Policht-Latawiec A. \& Włodzimierz K. 2017. The impact of anthropopressure on physicochemical state of the korzkiewka stream. Journal of Ecological Engineering, 18(5), 199-208.

3. Rahim A., Tri R. 2019. Water Pollution Index of Batujai Reservoir, Central Lombok Regency-Indonesia. Journal of Ecological Engineering, 20(3), 219-225.

4. Tjahjono A., Azis Nur B., Sutrisno A. 2017. Analysis of heavy metal content of $\mathrm{pb}$ in ballast water tank of commercial vessels in port of Tanjung Emas Semarang, central java province. Journal of Ecological Engineering, 18(2), 7-11.

5. Biney C., Amuzu A.T., Calamari D., Kaba N., Mbome I.L., Naeve H., Ochumba O., Osibanjo O., Radegonde V., Saad M.A.H. 1991. Etude des métaux lourds. Revue de la pollution dans l'environnement aquatique africain, 25, 1-16.

6. Ejupi N., Bardha K., Bujar D., Arbana Durmishi D., Egzona E., Murtezan I., Jashari A., Shabani A. 2018. The Distribution of Metals in Sediments of the Likova, Kumanova and Pçinja Rivers: Spring Season. Journal of Ecological Engineering, 19(3), 80-92. 
7. El Bouch M. 1996. Etude physicochimique des éléments traces (stables et radioactifs) dans les eaux naturelles. Application aux eaux du bassin de Lodève (Herault, France). Ph.D. Thesis. Montpellier II University, Montpellier.

8. La Force M.J., Fendorf S.E., Li G.C, Schneider G.M., Rsenzweing R.F. 1998. A laboratory evaluation of trace elements mobility from flooding and nutrient loading of Coeur d'Alene river sediments, Journal of Ecological Engineering, 27(2), 318-328.

9. Forstner U. 1987. Metal speciation in solid wastes. Factors affecting mobility. In: Speciation of Metals in Water, Sediment and Soil Systems. Lecture Notes in Earth Sciences, 11, 13-41. Landner L. (eds) Springer, Berlin, Heidelberg.

10. Forstner U., Salomons W. 1980. Trace metal analysis on polluted sediments. Part I. Assessment of sources and intensities. Environmental Technology Letters, 1(11), 494-505.

11. Jensen H.S., Kristensen P., Jeppesen E., Skytthe A. 1992. Iron:phosphorus ratio in surface sediment as an indicator of phosphate release from aerobic sediments in shallow lakes. Hydrobiologia, 235, 731-743.

12. ISO. 1994. Qualité de l'eau-échantillonnage-guide pour la conservation et la manipulation des échantillons. 5667-3, France.

13. Golterlan H.L. 1988. The calcium and iron bound phosphate phase diagram. Hydrobiologia, 159, 149-151.

14. Kadriu S., Malollari I., Pula-Beqiri .L, Aliu M., Sadiku M., Baruti B., Kelmendi M., 2017. Presence of heavy metals in water and sediment of rivers Trepça and Sitnica. Journal of Environmental Protection and Ecology, 18(1), 10-21.

15. Karrouch L., Chahlaoui A. 2009. Bio-évaluation de la qualité des eaux de l'oued Boufekrane (Meknes, Maroc). Biomatec Echo. 3(6), 6-17.

16. Knudsen W.C., Banks P.M., Winningham J.D., Klumpar D.M. 1977. Numerical model of the convecting F2 ionosphere at high latitudes. Journal of Geophysical Research, 79(7), 1046-1055.

17. Malle K.G. 1992. Zink in der Umwelt. Acta Hydrochimica et Hydrobiologica, 20, 196-204.

18. Mesrar L. 2013. Caractérisation géochimique, minéralogique, technologique et nanotechnologique des marnes miocènes du couloir sud rifain (Fès
Taza): études et valorisations. Ph.D. Thesis, Sidi Mohammed Ben Abdellah University, Fes.

19. ME-MPUPHE (Minister of Equipment and the Minister for Planning, Urban Planning, Housing and Environment, 2002. Surface water quality grid. Decree No. 1275-02 of 17 October 2002. Official bulletin, Morocco.

20. Meybeck M. 1986. Composition chimique des ruisseaux non pollués de France. Sciences Géologiques, bulletins et mémoires, 39(1), 3-77.

21. Noori R., Sabahi M.S., Karbassi A.R., Baghvand A., Taati Zadeh H. 2010. Multivariate statistical analysis of surface water quality based on correlations and variations in the data set. Desalination, 260(1-3), 129-136.

22. Naoura J. 2012. Caractérisation hydrologique et qualitative des eaux de surface du bassin versant du haut Inaouene. Ph.D. Thesis, Sidi Mohammed Ben Abdellah University, Fes,

23. Naser B., Granit K., Ilir M., Ylber B. 2019. Exploration of Physico-Chemical Parameters in Environmental Matrices of the River Cerica and a Segment of the River Drini I Bardhë. Journal of Ecological Engineering, 20(4), 127-135.

24. Rodier J., Legube B., Merlet N., coll. 2009. L'analyse de $1^{\prime}$ eau. 9e Ed. Dunod, Paris.

25. Rodier J., Beuffr H., Bournaud M., Broutin J.P. Geoffray Ch., Kovacsik G., Laport J., Pattee E., Plissier M., Rodi L., Vial J. 1984. L'analyse de l'eau, eaux naturelles, eaux résiduaires, eau de mer. $7 \mathrm{e}$ Ed. Dunod, Paris.

26. Rejsek F. 2002. Analyse des eaux: Aspects réglementaires et techniques. Canopé-CRDP, Bordeaux.

27. Taoufik M., Dafir J.E. 2002. Changes of the phosphorus in sediments of the dams in the down part of Oum Rabiaa basin (Morocco). Journal of Water Sciences, 15(1), 235-249

28. Taylor S.R. 1964. Abundance of chemical elements in the continental crust: a new table. Geochimica et Cosmochimica Acta, 28(8), 1273-1285.

29. World Bank. 2017. Managing Urban Water Scarcity in Morocco. Water Partner Program. World Bank, Washington.

30. Zhang J., Huang W.W. 1993. Dissolved trace metals in the Huanghe: the most turbid large rive in the World. Water Research, 27(1), 1-8. 